\title{
FAKTOR YANG MEMPENGARUHI PENETAPAN HOTEL X SEBAGAI WEDDING VENUE
}

\author{
Vera Sriyani \\ Program Studi Magister Manajemen Universitas Tarumanagara \\ verasriyani@yahoo.com
}

Masuk : 30-11-2017, revisi : 21-12-2017 diterima untuk diterbitkan : 21-12-2017

\begin{abstract}
Wedding is one of the most important events for couples, so mostly they want their wedding event as perfect as possible. Choosing wedding venue is the first step to prepare wedding. The purpose of this research is to determine factors affect the selection of wedding venue at Hotel X. The respondent of this research is 203 prospective wedding couples who came to Hotel X. The method used in this research is multivariate analyist. This study obtained data via questionnaires and used statistical tests such as F-Test, $\mathrm{R}$ Square $\left(\mathrm{R}^{2}\right)$-Test, and TTest. The result of this study shows location, atmosphere, facility, food, service and price are factors which has a significant influence on prospective wedding couple's purchase decision.

Keywords: Availability, Location, Atmosphere, Facility, Food, Service, Price, Purchase Decision, Hospitality, Wedding
\end{abstract}

\section{PENDAHULUAN}

Memilih wedding venue merupakan langkah awal dalam mempersiapkan sebuah acara pernikahan. Dengan situasi seperti ini banyak hotel menggunakan peluang tersebut untuk memaksimalkan pendapatannya. Selain punya kesan mewah dan prestigious, hotel juga merupakan tempat pernikahan dengan fasilitas yang paling lengkap. Meskipun permintaan akan vendor wedding venue meningkat, namun banyaknya hotel baru berdiri dan menawarkan jasa yang sama, membuat persaingan usaha semakin sulit. Persaingan tersebut juga dapat kita lihat dari banyaknya hotel yang saling mencuri customer, mulai dari fleksibel dengan harga yang mengikuti budget customer bahkan sampai memberikan harga dibawah standar hotel-nya.

Hotel X merupakan salah satu hotel yang mengalami dampak dari persaingan yang semakin berat tersebut. Meskipun permintaan akan vendor wedding venue meningkat, namun penjualan wedding venue pada Hotel $\mathrm{X}$ tidak mengalami peningkatan yang signifikan. Untuk menciptakan keunggulan bersaing Hotel $\mathrm{X}$ harus dapat mengenali dan memahami kebutuhan dan harapan dari para calon pengantin. Kesuksesan sebuah perusahaan bergantung dengan bagaimana cara perusahaan tersebut mengerti kebutuhan customer-nya dan memenuhi kebetuhan tersebut melampaui harapan customer (Yang et al., 2009). Banyak faktor yang mempengaruhi calon pengantin dalam memilih wedding venue. Berdasarkan penelitian terdahulu, ada 7 faktor utama yang menjadi pertimbangan calon pengantin dalam memilihi wedding venue, yaitu: ketersediaan (availability), lokasi (location), atmosfir (atmosphere), fasilitas (facility), makanan (food), pelayanan (service), harga (price). Namun penelitian terdahulu dilaksanakan di Hongkong dan Thailand. Pada penelitian kali ini peneliti menelusuri apakah ketujuh faktor tersebut juga berpengaruh di Hotel X yang berlokasi di Indonesia Oleh karena itu penulis mengambil judul penelitian "Faktor yang Mempengaruhi Penetapan Hotel X Sebagai Wedding Venue.

\section{TINJAUAN PUSTAKA}

\section{Faktor yang Mempengaruhi Pemilihan Wedding Venue}

Sama dengan event - event lain, pernikahan merupakan kesatuan yang unik yang didapat dari interaksi antara pengaturan, sumber daya manusia, dan sistem manajemen (Getz, 2008). Bodwin et al. (2006) mengungkapkan bahwa pemilihan tempat merupakan keputusan penting 
karena akan mempengaruhi elemen acara lainnya. Sehingga dapat di simpulkan hal-hal yang menjadi pertimbangan dari sebuah tempat acara pernikahan adalah ketersediaan (availability), lokasi (location), atmosfir (atmospherics), fasilitas (facility), makanan (food), kualitas pelayanan (service), dan harga (price) (Lau \& Hui, 2010).

\section{Availability (Ketersediaan)}

Salah satu faktor yang mempengaruhi minat beli konsumen adalah faktor ketersediaan produk (Kotler, 2005). Ketersediaan merupakan kecocokan antara permintaan dengan tempat yang masih dapat dijual. Forsyth (1999) mendefinisikan ketersediaan adalah saat dimana tempat tersebut masih dapat dipesan ketika tamu menginginkannya. Kesulitan untuk mendapatkan tempat pernikahan dengan tanggal yang telah ditentukan membuat beberapa fasilitas penunjang acara tersebut harus dipesan dari jauh hari seperti satu tahun sebelum acara atau bahkan lebih (Goldman \& Eyster, 1992). Lau \& Hui (2010) dalam penelitiannya menemukan ketersediaan Ballroom pada tanggal baik pernikahan merupakan faktor terakhir yang mempengaruhi calon pengantin dalam memilih wedding venue. Napompech (2014) menemukan terdapat pengaruh yang signifikan dari faktor availability terhadap keputusan pembelian calon pengantin dalam memilih wedding venue.

\section{Lokasi (Location)}

Menurut Swastha (2002:24), "Lokasi adalah tempat dimana suatu usaha atau aktivitas usaha dilakukan". Lokasi yang "baik" akan meningkatkan nilai dari suatu tempat pernikahan (Bull, 1994). Lokasi pesta pernikahan yang baik tidak hanya bagus namun juga harus dapat memberikan kenyamanan kepada para tamu (Callan \& Hoyes, 2000). Bodwin et al. (2006) mengidentifikasikan lokasi yang baik tidak cukup hanya mudah jangkau oleh sarana transportasi dan keadaan di sekitar lokasi, namun juga ketersediaan area lahan parkir, dekat dengan sarana transportasi umum dan mudah dijangkau dalam waktu singkat. Lokasi merupakan faktor yang berpengaruh secara signifikan bagi tamu dalam menentukan restoran (Austin et al., 2005; Tzeng et al., 2002; Chou et al., 2008). Menemukan lokasi yang baik merupakan faktor penting yang dapat menentukan kesuksesan bisnis hotel maupun restaurant.

\section{Atmosfir (Atmospherics)}

Atmosfir adalah suasana terencana yang sesuai dengan pasar sasarannya dan yang dapat menarik konsumen untuk membeli (Kotler, 2005). Atmosfer dapat mempengaruhi keadaan emosi pembeli yang menyebabkan atau mempengaruhi pembelian. Atmosfir berkaitan erat dengan design dari sebuah tempat yang dapat menciptakan efek emosional, dan meliputi fasilitas yang berwujud maupun tidak berwujud termasuk desain, kebersihan, ambience, dan dekorasi merupakan sarana berkomunikasi dengan tamu (Liu \& Jang, 2009). Kemewahan dan kekhimadan yang diciptakan oleh objek/materi tertentu akan memberikan dampak terhadap upacara pemberkatan dan pesta pernikahan. Sun et al. (1999) menambahkan di samping kualitas makanan dan image, kebersihan merupakan salah satu faktor penting dalam memilih tempat pernikahan. Atmosfir suatu restoran yang baik, sangat mempengaruhi kepuasan tamu yang datang yang berdampak pada keinginan untuk datang kembali, positif review, dan kemauan untuk membayar lebih (Berry et al, 2002; Sulek \& Hensley, 2004; Countryman \& Jang, 2006; Namkung \& Jang, 2008; Heung \& Gu, 2012). Djawoto (2016) menemukan terdapat pengaruh signifikan atmosfer toko terhadap keputusan pembelian.

\section{Fasilitas (Facility)}

Fasilitas merupakan segala sesuatu yang bersifat peralatan fisik yang disediakan oleh pihak penjual jasa untuk mendukung kenyamanan konsumen (Kotler, 2009:45). Fasilitas merupakan wujud fisik dari sebuah tempat pernikahan, seperti ukuran ballroom, sound system, fasilitas kamar pengantin, dan akomodasi yang ditawarkan. Callen dan Hoyes (2000) berpendapat besar ruangan merupakan sarana utama yang dapat dilihat dan diukur dari sebuah tempat. Ukuran dan tata ruang sebuah tempat akan mempengaruhi kapasitasnya secara langsung. Fasilitas kamar pengantin dibutukan untuk persiapan pernikahannya seperti makeup, mengenakan gaun, dan sebagainya. Untuk menentukan strategi besaing, kamar pengantin 
dan akomodasi kamar lainnya harus sudah termasuk dalam paket pernikahan (Adler \& Chien, 2004). Lempoy et al., (2015) menemukan terdapat pengaruh signifikan fasilitas terhadap keputusan pembelian. Fasilitas memiliki pengaruh positif yang signifikan serta memberikan kontribusi yang cukup besar terhadap keputusan membeli suatu produk.

\section{Makanan (Food)}

Foods atau masakan merupakan produk inti dari restoran dan memiliki peran penting dalam pengalaman makan seorang pelanggan (Liu \& Jang, 2009). Menu yang ditawarkan dan kualitas makan juga merupakan hal penting dalam sebuah pesta pernikahan. Rasa, kesegaran, temperatur, presentasi (warna, bentuk, dan penampilan) bahan makanan dan variasi menu merupakan indikator dari kualitas makan (Baek et al., 2006; Liu \& Jang, 2009; Abdullah \& Hamdan, 2012). Lau dan Hui (2010) dalam penelitiannya menemukan, kualitas bahan makanan merupakan faktor terpenting ketiga bagi calon pengantin dalam memilihi tempat pernikahan. Auty (1992) berpendapat jenis dan kualitas makanan menjadi variabel yang paling berpengaruh dalam memilih restoran.

\section{Pelayanan (Service)}

Menurut Zeithaml (1996) kualitas pelayanan (service quality) merupakan kemampuan memberikan pelayanan sesuai atau melebihi dari yang diinginkan konsumen. Menurut Cheng et al., (2008) sikap dan perilaku pelayanan karyawan memberikan kontribusi yang signifikan. Lau dan Hui (2010) menemukan bahwa attitude karyawan merupakan faktor yang paling penting bagi calon pengantin dalam menentukan tempat pernikahan.

\section{Harga (Price)}

Menurut Kotler \& Amstrong (2003), "Price stands for the amount of money that the customer has to pay to obtain the product". Harga juga memainkan peranan penting dalam mengkonsumsikan kualitas dari jasa tersebut. Yang termasuk dalam karakteristik harga adalah harga sewa ruangan, harga makanan dan minuman, harga paket, dan biaya peralatan lainnya. Lockyer (2005) menemukan harga menjadi pertimbangan yang sangat penting dalam proses pemilihan tempat. Klepsch dan Schneider (2012) dalam penelitiannya "The Influence of Sustainable Hotel Practices on Consumer Buying Decision”, menemukan harga merupakan faktor utama dalam menentukan keputusan pembelian.

\section{Penelitian Terdahulu}

Hasil survey Lau dan Hui (2010) dalam penelitiannya "Selection Attributes of Wedding Banquet Venues: An Exploratory Study of Hong Kong Prospective Couple" menemukan bahwa attitude karyawan merupakan faktor yang paling penting bagi calon pengantin dalam menentukan tempat pernikahan. Kebersihan dan kualitas makanan juga menjadi faktor penting dalam menentukan tempat pernikahan setelah attitude karyawan. Dimana tanggal baik menjadi faktor terakhir yang menjadi pertimbangan calon pengantin dalam memilih wedding venue.

Penelitian tentang faktor yang mempengaruhi calon pengantin dalam menentukan wedding venue juga diteliti Napompech (2014). Dalam penelitiannya yang berjudul "Factors Affecting Wedding Banquet Venue Selection of Thai Wedding Couple", ditemukan pelayanan yang baik dari staff hotel merupakan faktor paling penting dalam memilih wedding venue. Sama dengan penilitian Lau \& Hui (2010), harga makanan dan minuman juga tidak menjadi faktor terpenting dalam memilih wedding venue. Namun, responden yang merencanakan pernikahan di hotel menjadikan faktor atmosfir ruangan (atmosphere) sebagai salah satu faktor penting dalam menentukan keputusan pembelian wedding venue. Hal ini disebabkan karena hotel memiliki kesan mewah, memiliki penataan ruangan yang rapi dan lebih baik bila dibandingkan gedung ataupun restoran.

\section{Keputusan Pembelian}

Menurut Peter dan Olson, "Keputusan pembelian adalah perilaku konsumen yang bersifat dinamis dan melibatkan interaksi antara pengaruh, kognisi (pikiran), lingkungan, dan kesediaan melakukan pertukaran." (Peter \& Olson, 2000). Keputusan pembelian merupakan hasil dari serangkaian proses keputusan konsumen. Langkah-langkah dalam proses keputusan 
konsumen meliputi: pengenalan kebutuhan, pencarian informasi, evaluasi alternatif, keputusan pembelian, perilaku pasca pembelian.

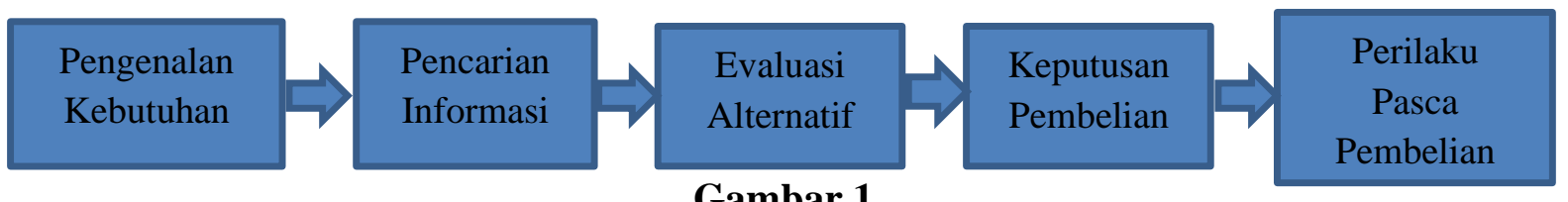

\section{Gambar 1}

Model Perilaku Keputusan Pembelian

Sumber: Kotler \& Amstrong (2008:179)

Kerangka Teori

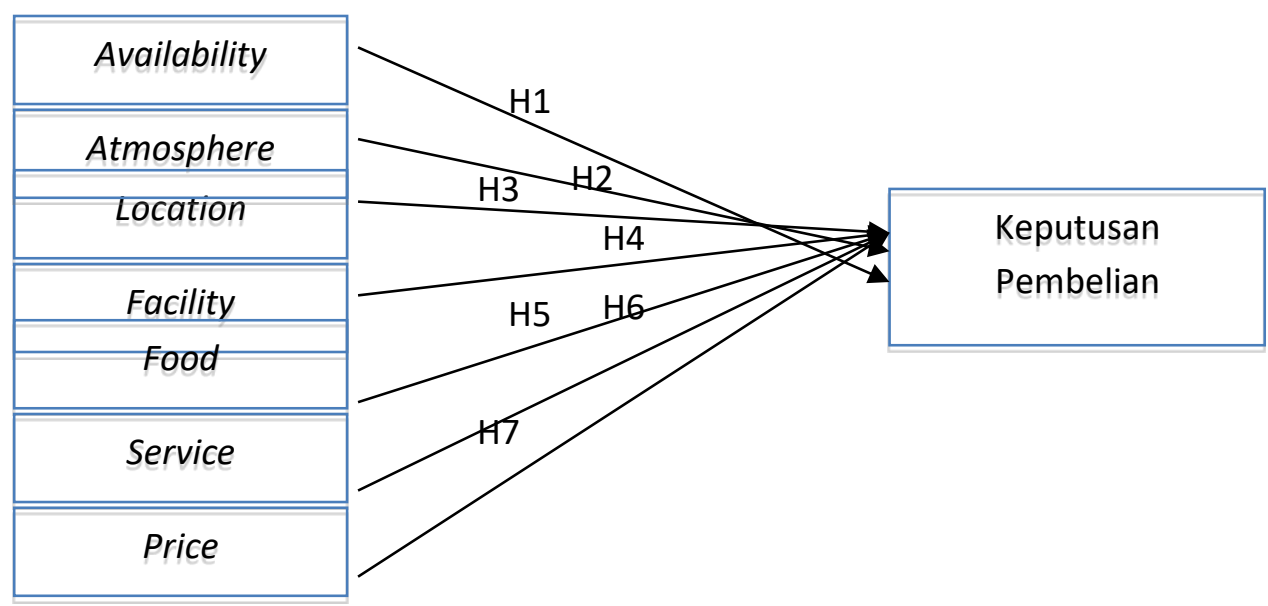

Gambar 2

Kerangka Pemikiran

\section{Hipotesis Penelitian}

Menurut Supranto (2009), "Hipotesis adalah suatu proposisi atau anggapan yang mungkin benar dan sering digunakan sebagai dasar pembuatan keputusan pemeahan persoalan ataupun untuk dasar penelitian lebih lanjut. Dalam penelitian ini penulis menguji 7 faktor, yang menjadi dasar pertimbangan calon pengantin dalam memilih tempat pernikahan.

H1: Terdapat pengaruh availability terhadap keputusan pembelian.

$\mathrm{H} 2$ : Terdapat pengaruh location terhadap keputusan pembelian.

H3: Terdapat pengaruh atmosphere terhadap keputusan pembelian.

H4: Terdapat pengaruh facility terhadap keputusan pembelian.

H5: Terdapat pengaruh food terhadap keputusan pembelian.

H6: Terdapat pengaruh service terhadap keputusan pembelian.

H7: Terdapat pengaruh price terhadap keputusan pembelian.

\section{METODOLOGI PENELITIAN}

\section{Sumber dan Pengumpulan Data}

Penelitian ini bertujuan untuk menguji pengaruh availability, lokasi, atmosfer, fasilitas, makanan, service dan harga terhadap keputusan pembelian wedding venue pada Hotel X. Data dalam penelitian ini diperoleh dari hasil pengisian kuesioner sebanyak 203 responden yang seluruhnya merupakan para calon pengantin yang datang ke Hotel X. Metode pemilihan sampel yang digunakan dalam penelitian ini adalah metode non-probability sampling. Metode pengukuran atas jawaban kuesioner untuk penelitian ini menggunakan teknik skala Likert yang terdiri atas 5 (lima) skor kategori, yaitu: 1 sangat tidak setuju sampai 5 sangat setuju.

\section{Metode Analisis Data}

\section{Uji F}

Pengujian ini dilakukan untuk mengetahui apakah seluruh variabel bebas $(\mathrm{X})$ secara bersama-sama berpengaruh signifikan atau tidak terhadap variabel tidak bebas (Y). Pengujian 
dilakukan dengan membandingkan nilai sig variabel secara keseluruhan dengan nilai $\alpha$. Penelitian ini menggunakan $\alpha$ sebesar 5\% (0.05).

\section{Uji R square $\left(\mathbf{R}^{2}\right)$}

Bertujuan untuk mengukur seberapa besar pengaruh variabel bebas (X) mempunyai kontribusi terhadap variabel tidak bebas $(\mathrm{Y})$ yaitu keputusan pembelian. Dimana $\mathrm{R}^{2}$ terletak antara 0 dan $1\left(0<\mathrm{R}^{2}<1\right)$.

\section{Uji T}

Dalam analisis regresi linear, uji t digunakan untuk mengetahui pengaruh parsial variabel bebas secara parsial terhadap variabel terikat dengan hipotesis pengujian yang digunakan adalah sebagai berikut: Dengan tingkat kepercayaan 95\%, maka Ho akan ditolak jika nilai signifikan <0,05 dan Ho akan diterima jika nilai signifikan $>0,05$.

\section{HASIL PENELITIAN}

Data hasil penelitian yang diperoleh selanjutnya dianalisis secara deskriptif dan kuantitatif untuk mengetahui gambaran availability, lokasi, atmosfer, fasilitas, makanan, service, harga dan keputusan pembelian wedding venue pada Hotel $\mathrm{X}$, serta untuk menguji pengaruh availability, lokasi, atmosfer, fasilitas, makanan, service dan harga terhadap keputusan pembelian wedding venue pada Hotel X. Analisis deskriptif dilakukan dengan melihat rata-rata dan standar deviasi maisng-maisng indikator sedangkan analisis kuantitatif dilakukan dengan menggunakan teknik analisis regresi linear berganda dengan bantuan program SPSS versi17.

\section{Uji Validitas dan Reliabikitas Instrumen}

Dalam penelitian ini, sebelum instrumen disebar pada seluruh responden, instrumen terlebih dahlu diuji cobakan pada 30 responden, selanjutnya dianalisis dengan menggunakan uji validitas dan reliabilitas.

\section{Uji Validitas}

Dalam uji validitas dengan menggunakan korelasi Pearson Product Moment, jika r hitung $>\mathrm{r}$ tabel dan nilai positif maka butir atau pertanyaan atau indikator tersebut dinyatakan valid dan sebaliknya (Ghozali, 2009:85). Nilai R tabel yang akan diperbandingkan dengan nilai $\mathrm{R}$ hitung masing-masing item pertanyaan adalah sebesar 0,361 ( $\mathrm{R}$ tabel pada $\mathrm{n}=30$ dan taraf signifikan 0,05).

Tabel 1

Hasil Uji Validitas Instrumen

\begin{tabular}{|l|l|l|l|l|}
\hline Variabel & Indikator & R Hitung & R Tabel & Validitas \\
\hline Availability & A & 1,000 & 0,361 & Valid \\
\hline \multirow{4}{*}{ Location } & L1 & 0,938 & 0,361 & Valid \\
\cline { 2 - 5 } & L2 & 0,891 & 0,361 & Valid \\
\cline { 2 - 5 } & L3 & 0,744 & 0,361 & Valid \\
\hline \multirow{5}{*}{ Atmosfir } & A1 & 0,918 & 0,361 & Valid \\
\cline { 2 - 5 } & A2 & 0,887 & 0,361 & Valid \\
\cline { 2 - 5 } & A3 & 0,895 & 0,361 & Valid \\
\cline { 2 - 5 } & A4 & 0,905 & 0,361 & Valid \\
\hline \multirow{5}{*}{ Facility } & FA1 & 0,863 & 0,361 & Valid \\
\cline { 2 - 5 } & FA2 & 0,884 & 0,361 & Valid \\
\cline { 2 - 5 } & FA3 & 0,912 & 0,361 & Valid \\
\cline { 2 - 5 } & FA4 & 0,935 & 0,361 & Valid \\
\hline FO1 & 0,920 & 0,361 & Valid \\
\cline { 2 - 5 } & FO2 & 0,912 & 0,361 & Valid \\
\cline { 2 - 5 } & FO3 & 0,837 & 0,361 & Valid \\
\cline { 2 - 5 } & FO4 & 0,866 & 0,361 & Valid \\
\cline { 2 - 5 } & FO5 & 0,901 & 0,361 & Valid \\
\hline Service & SVC & 1,000 & 0,361 & Valid \\
\hline \multirow{5}{*}{ Price } & P1 & 0,956 & 0,361 & Valid \\
\cline { 2 - 5 } & P2 & 0,965 & 0,361 & Valid \\
\hline & PD1 & 0,906 & 0,361 & Valid \\
\cline { 2 - 5 } & PD2 & 0,919 & 0,361 & Valid \\
\cline { 2 - 5 } & PD3 & 0,898 & 0,361 & Valid \\
\cline { 2 - 5 } & PD4 & 0,939 & 0,361 & Valid \\
\hline
\end{tabular}


Berdasarkan tabel di atas, nilai $\mathrm{R}$ hitung $>\mathrm{R}$ tabel yang berarti seluruh item dalam instrumen penelitian ini valid dalam mengukur variabel penelitian, dengan demikian seluruh item dalam instrumen penelitian ini dapat digunakan.

\section{Uji Reliabilitas}

Dalam Uji Reliabilitas dengan Cronbachs Alpha, instrumen penelitian dinyatakan reliabel jika memiliki nilai crombac's alpha $>0,6$ (Ghozali, 2006). Berikut ini adalah hasil uji reliabilitas keempat instrumen penelitian:

\section{Tabel 2}

Hasil Uji Reliabilitas

\begin{tabular}{|l|l|l|}
\hline Variabel & Crombachs Alpha & Reliabilitas \\
\hline Availability & 1,000 & reliabel \\
\hline Location & 0,830 & reliabel \\
\hline Atmosfir & 0,921 & reliabel \\
\hline Facility & 0,919 & reliabel \\
\hline Food & 0,923 & reliabel \\
\hline Service & 1,000 & reliabel \\
\hline Price & 0,919 & reliabel \\
\hline Purchase Decision & 0,934 & reliabel \\
\hline
\end{tabular}

\section{Karakteristik Responden}

Jumlah responden dalam penelitian ini adalah sebanyak 203 responden. Sebagian besar responden berjenis kelamin wanita $(59,61 \%)$ dan berjenis kelamin pria $(40,39 \%)$. Sebagian besar responden berusia 21-25 tahun $(44,83 \%)$, (22,6\%) berusia $26-30$ tahun, $(16,75 \%)$ berusia 31-35 tahun, $(9,36 \%)$ berusia $<20$ tahun dan $(2,46 \%)$ responden berusia $>40$ tahun.

Dari segi pendidikan, sebagian besar responden berpendidikan S1 $(65,02 \%)$ sedangkan sisanya didominasi oleh responden dengan pendidikan SMA, D3, S2 dan lain-lain. Selanjutnya dari segi pekerjaan, sebagian besar responden merupakan karyawan swasta $(53,69 \%)$, sedangkan sisanya sebanyak $26,11 \%$ responden merupakan wiraswasta dan $10,34 \%$ responden tidak bekerja.

Selanjutnya dari segi biaya yang dikeluarkan untuk wedding venue, sebagian besar responden mengeluarkan biaya antara $\operatorname{Rp} 200.000 .000$ - Rp 300.000 .000 (32,02\%), sedangkan sisanya sebanyak (26,11\%) mengeluarkan biaya Rp 100.000.000 - Rp 200.000.000, (15,27\%) responden mengeluarkan biaya < Rp 100.000.000 dan sebanyak $(6,90 \%)$ responden mengeluarkan biaya $>$ Rp 400.000.000.

\section{Uji Prasyarat Analisis Regresi}

Dalam penelitian ini, pengaruh availability, lokasi hotel, atmosfer, fasilitas hotel, makanan hotel, service dan harga hotel terhadap keputusan pembelian pengunjung Hotel X akan dianalisis dengan menggunakan teknik analisis regresi linear berganda. Sebelum dilakukan analisis regresi di ketiga model, perlu dilakukan uji asumsi klasik untuk menguji apakah analisis regresi dapat digunakan. Uji asumsi tersebut meliputi uji normalitas, uji multikolinearitas, uji heteroskedastisitas dan uji autokorelasi.

\section{Uji Normalitas}

Uji Normalitas dilakukan untuk mengetahui distribusi residual dari model regresi, jika residual berdistribusi normal maka model dapat dianalisis dengan analisis regresi, namun jika residual tidak berdistribusi normal maka model tersebut tidak dapat dianalisis dengan analisis regresi. Pada grafik PP Plot, jika data residual berpencar di sekitar garis lurus maka dikatakan data residual berdistribusi normal dan pada uji normalitas Kolmogorv Sminov, data residual dikatakan berdistribusi normal jika nilai probabilitas (signifikan) lebih besar dari 0,05.

\section{Hasil Uji Normalitas PP Plot}

Berdasarkan gambar di bawah, data hasil penelitian menyebar mengikuti arah garis lurus, sehingga dapat disimpulkan bahwa secara grafik, residual model berdistribusi normal. 

Normal P-P Plot of Regression Standardized

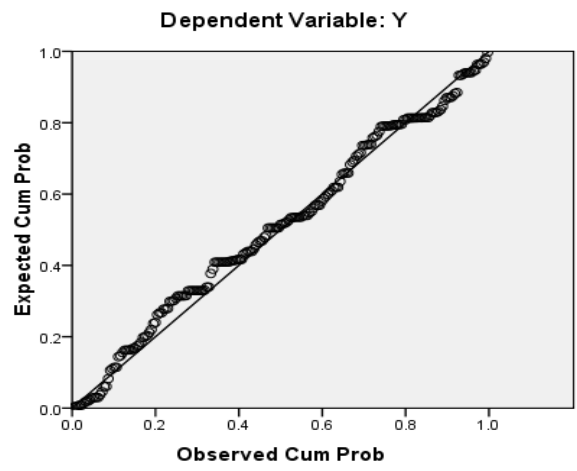

Gambar 3

Hasil Uji Normalitas

Uji Multikolinearitas

Tabel 3

Hasil Uji Multikolinearitas

Coefficients ${ }^{\mathrm{a}}$

\begin{tabular}{|ll|l|l|}
\hline \multirow{2}{*}{ Model } & & \multicolumn{2}{|l|}{ Collinearity Statistics } \\
\cline { 3 - 4 } & & Tolerance & VIF \\
\hline 1 & X1 & .593 & 1.686 \\
& X2 & .307 & 3.261 \\
& X3 & .237 & 4.217 \\
& X4 & .318 & 3.141 \\
& X5 & .293 & 3.416 \\
& X6 & .462 & 2.164 \\
X7 & .564 & 1.772 \\
\hline
\end{tabular}

Berdasarkan tabel 3 di atas, dapat dilihat nilai VIF seluruh variabel $<10$ dan nilai tolerance $>0,1$, hal ini menunjukkan tidak terjadi multikolinearitas pada model regresi, sehingga asumsi tidak adanya multikolinearitas terpenuhi.

\section{Uji Heteroskedastisitas}

Uji heterokedastisitas bertujuan menguji apakah dalam model regresi terjadi ketidaksamaan variance dari residual satu pengamatan ke pengamatan yang lain. Ada beberapa cara yang dapat dilakukan untuk melakukan uji heteroskedastisitas, yaitu uji grafik plot, uji park, uji glejser, dan uji white. Pengujian pada penelitian ini menggunakan Grafik Plot antara nilai prediksi variabel dependen yaitu ZPRED dengan residualnya SRESID. Tidak terjadi heteroskedastisitas apabila tidak ada pola yang jelas, serta titik-titik menyebar di atas dan di bawah angka 0 pada sumbu Y (Ghozali, 2011: 139-143). Berikut ini adalah grafik hasil uji heteroskedastisitas tersebut:

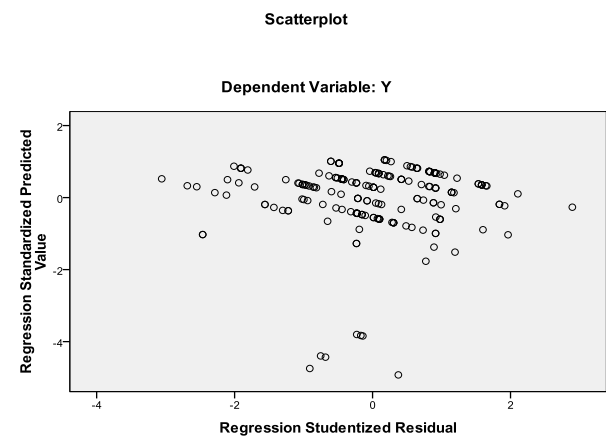

Gambar 4

Hasil Uji Heteroskedastisitas Grafik 
Berdasarkan tabel di atas, tidak ada pola yang jelas, serta titik-titik menyebar di atas dan di bawah angka 0 pada sumbu Y yang berarti tidak terjadi heteroskedastisitas.

\section{Uji Autokorelasi}

Uji Autokorelasi dapat dilakukan dengan menggunakan uji Run. Dalam uji Run, apabila nilai signifikan hasil pengujian > 0,05 maka dinyatakan tidak terjadi autokorelasi dalam model, sedangkan nilai signifikan $<0,05$ menunjukkan adanya autokorelasi dalam tabel.

\section{Tabel 4}

\section{Hasil Uji Autokorelasi}

Runs Test

\begin{tabular}{|l|l|}
\hline & abs \\
\hline Test Value $^{\mathrm{a}}$ & .76 \\
Cases < Test Value & 101 \\
Cases >= Test Value & 102 \\
Total Cases & 203 \\
Number of Runs & 99 \\
Z & -.492 \\
Asymp. Sig. (2-tailed) & .623 \\
\hline
\end{tabular}

Berdasarkan tabel di atas, diperoleh nilai signifikan hasil uji Run sebesar 0,623. Oleh karena nilai signifikan yang diperoleh $>0,05$, hal ini menunjukkan bahwa tidak terjadi autokorelaasi pada ketiga model regresi.

\section{Hasil Analisis Regresi}

Hasil analisis regresi meliputi hasil uji t (uji pengaruh parsial), hasil uji $\mathrm{F}$ (uji pengaruh simultan) dan Koefisien Determinasi.

\section{Uji Pengaruh Parsial (Uji t)}

\section{Tabel 5}

\section{Hasil Uji t}

Coefficients $^{\mathrm{a}}$

\begin{tabular}{|ll|l|l|l|l|l|}
\hline \multirow{2}{*}{ Model } & \multicolumn{3}{|l|}{ Unstandardized Coefficients } & $\begin{array}{l}\text { Standardized } \\
\text { Coefficients }\end{array}$ & & \\
\cline { 2 - 6 } & & $\mathrm{B}$ & Std. Error & Beta & $\mathrm{t}$ & Sig. \\
\hline & (Constant) & 1.253 & .592 & & 2.115 & .036 \\
& Availability & -.033 & .050 & -.037 & -.653 & .515 \\
& Lokasi & .153 & .072 & .122 & 2.132 & .034 \\
& Atmosfer & .116 & .057 & .133 & 2.043 & .042 \\
& Fasilitas & .694 & .114 & .250 & 6.088 & .000 \\
& Makanan & .110 & .046 & .140 & 2.388 & .018 \\
& Servis & 1.173 & .160 & .342 & 7.342 & .000 \\
Harga & .241 & .063 & .160 & 3.802 & .000 \\
\hline
\end{tabular}

a. Dependent Variable: Purchase_Decision

Berdasarkan tabel di atas, diperoleh beberapa hasil sebagai berikut :

1. Nilai signifikan variabel availability adalah sebesar 0,515 dengan koefisien regresi bertanda negative disimpulkan bahwa availability tidak berpengaruh terhadap keputusan pembelian wedding venue pada Hotel X.

2. Nilai signifikan variabel lokasi adalah sebesar 0,034 ; atmosfer adalah sebesar 0,042 ; fasilitas adalah sebesar 0,000 makanan adalah sebesar 0,018; servis adalah sebesar 0,000; harga adalah sebesar 0,000 dengan koefisien regresi bertanda positif yang berarti Ho ditolak dan disimpulkan bahwa ke enam variabel berpengaruh signifikan terhadap keputusan pembelian wedding venue pada Hotel X, yaitu semakin sesuai harga Hotel X maka keputusan pembelian pengunjung akan semakin tinggi begitu sebaliknya. 


\section{Uji Pengaruh Parsial (Uji t)}

Dalam penelitian ini, uji pengaruh simultan digunakan untuk menguji pengaruh variabel availability, lokasi, fasilitas, servis, harga hotel, atmosfer dan makanan hotel terhadap keputusan pembelian pengunjung hotel $\mathrm{X}$ dengan hipotesis pengujian yang digunakan: Dengan tingkat kepercayaan 95\%, maka Ho akan ditolak jika nilai signifikan $<0,05$ dan Ho akan diterima jika nilai signifikan $>0,05$

Tabel 6

Hasil Uji Pengaruh Simultan

\begin{tabular}{|c|c|c|c|c|c|c|}
\hline \multicolumn{7}{|c|}{ ANOVA $^{b}$} \\
\hline & & Sum of Squares & $\mathrm{df}$ & Mean Square & $\mathrm{F}$ & Sig. \\
\hline \multirow[t]{3}{*}{1} & Regression & 1143.876 & 7 & 163.411 & 114.959 & $.000^{\mathrm{a}}$ \\
\hline & Residual & 277.188 & 195 & 1.421 & & \\
\hline & Total & 1421.064 & 202 & & & \\
\hline
\end{tabular}

a. Predictors: (Constant), Harga, Atmosfer, Fasilitas, Servis, Availability, Lokasi, Makanan

b. Dependent Variable: Purchase_Decision

Berdasarkan tabel di atas, diperoleh nilai signifikan hasil uji F sebesar 0,000. Oleh karena nilai signifikan hasil uji simultan $<0,05$ maka Ho ditolak dan disimpulkan bahwa variabel ketersediaan, lokasi, fasilitas, servis, harga, atmosfer dan makanan hotel secara simultan berpengaruh terhadap keputusan pembelian.

\section{Koefisien Determinasi}

Dalam penelitian ini, koefisien determinasi digunakan untuk mengetahui besar pengaruh variabel ketersediaan, lokasi, fasilitas, servis, harga atmosfer dan makanan hotel secara simultan terhadap keputusan pembelian. Nilai koefisien determinasi dilihat dari nilai R Square.

Tabel 7

\section{Koefisien Determinasi}

Model Summary
\begin{tabular}{|l|l|l|l|l|}
\hline Model & $\mathrm{R}$ & R Square & Adjusted R Square & $\begin{array}{l}\text { Std. Error of the } \\
\text { Estimate }\end{array}$ \\
\hline 1 & $.897^{\mathrm{a}}$ & .805 & .798 & 1.19226 \\
\hline
\end{tabular}
a. Predictors: (Constant), Harga, Atmosfer, Fasilitas, Servis, Availability, Lokasi,
b. Dependent Variable: Purchase_Decision

Berdasarkan Tabel 7 di atas, nilai koefisien determinasi model adalah 0,805 yang berarti besar kontribusi yang diberikan variabel availability, lokasi, fasilitas, servis, harga, atmosfer dan makanan hotel secara simultan terhadap keputusan pembelian wedding venue pada Hotel $\mathrm{X}$ adalah $80,5 \%$, sedangkan sisanya sebanyak $19,5 \%$ keputusan pembelian Hotel $\mathrm{X}$ dipengaruhi oleh faktor lain di luar variabel ketersediaan, lokasi, fasilitas, servis, harga, atmosfer dan makanan.

\section{Pengujian Hipotesis}

1. Availability (ketersediaan) tidak berpengaruh terhadap keputusan pembelian wedding venue pada Hotel $\mathrm{X}$, sehingga hipotesis 1 tidak diterima.

2. Location (lokasi) berpengaruh positif dan signifikan terhadap keputusan pembelian wedding venue pada Hotel $\mathrm{X}$, sehingga hipotesis 2 diterima.

3. Atmosphere (atmosfer) berpengaruh positif dan signifikan terhadap keputusan pembelian wedding venue pada Hotel $\mathrm{X}$, sehingga hipotesis 3 diterima.

4. Facility (fasilitas) berpengaruh positif dan signifikan terhadap keputusan pembelian wedding venue pada Hotel $\mathrm{X}$, sehingga hipotesis 4 diterima.

5. Food (makanan) berpengaruh positif dan signifikan terhadap keputusan pembelian wedding venue pada Hotel $\mathrm{X}$, sehingga hipotesis 5 diterima.

6. Service (kualitas pelayanan) berpengaruh positif dan signifikan terhadap keputusan pembelian wedding venue pada Hotel $\mathrm{X}$, sehingga hipotesis 6 diterima. 
7. Price (harga) berpengaruh positif dan signifikan terhadap keputusan pembelian wedding venue pada Hotel $\mathrm{X}$, sehingga hipotesis 7 diterima.

\section{KESIMPULAN \& SARAN \\ Kesimpulan}

1. Availability tidak berpengaruh terhadap keputusan pembelian wedding venue pada Hotel $\mathrm{X}$, sehingga Ho diterima.

2. Location, Atmosphere, Facility, Food, Service and Price berpengaruh signifikan Saran terhadap keputusan pembelian wedding venue pada Hotel X, sehingga Ho ditolak.

Saran yang dapat disampaikan dari hasil penelitian ini adalah :

1. Bagi pihak hotel agar terus meningkatkan pelayanan hotel terutama dalam hal kualitas makanan sehingga keputusan pembelian pengunjung semakin tinggi, pihak hotel juga perlu meningkatkan kualitas sound systemnya agar lebih mendukung kegiatan kegiatan yang dilaksanakan di ballroom hotel.

2. Bagi penelitian selanjutnya dapat melakukan penelitian dengan jenis responden yang berbeda dan lokasi berbeda serta dapat juga menggunakan alat analisis yang berbeda seperti analisis SEM atau PLS.

\section{DAFTAR PUSTAKA}

Kotler, P. (2005). Manajamen Pemasaran (Jilid 1 \& 2). Jakarta: PT. Indeks Kelompok Gramedia.

Lau, C. K. \& Hui, S. H. (2010). Selection attributes of wedding banquet venues: An exploratory study of Hong Kong prospective wedding couples. International. Journal of Hospitality Management, 29, 268-276.

Liu, Y., \& Jang, S. (2009). The effects of dining atmospherics: An extended Mehrabian Russell model. International Journal of Hospitality Management, 28(4), 494-503

Napompech, K. (2014). Factors affecting wedding banquet venue selection of Thai wedding couples. Journal of Applied Sciences, 14(19, 2258-2266

Peter, P. J. \& Olson, C. J. (1999). Perilaku Konsumen dan Strategi Pemasaran (4 ${ }^{\text {th }}$ ed.). Jakarta: Erlangga.

Yang, C. C., Cheng, L. Y., Sung, D. \& Withiam, G. (2009). Strategic-pricing policy based on analysis of service attributes. Cornell Hosp. Q, 50, 498-500 